Part of Journal of Research of the National Bureau of Standards, Volume 33, September 1944

\title{
STRESS-CORROSION TESTS OF BRIDGE-CABLE WIRE
}

\author{
By Rolla E. Pollard
}

\section{ABSTRACT}

Stress-corrosion cracks were produced in several statically stressed specimens of cold-drawn wire from the Portsmouth Bridge and in one specimen of heattreated wire from the Mt. Hope Bridge by immersion in dilute nitrate solutions. No cracks were produced in the cold-drawn Mt. Hope replacement wire after long exposure. No cracks were produced by immersing similar specimens in more corrosive media such as distilled water or dilute ammonium sulfate or in inhibitive solutions such as dilute ammonium nitrate or dilute sodium hydroxide. The results conform, in this respect, to the selective corrosion theory of intercrystalline attack. However, due to the limited amount of materials and their incompletely known history, the effect of such factors as composition, fabrication and heat treatment of the steel could not be determined.

\section{CONTENTS}

I. Introduction

II. Materials $\ldots$

III. Stress-corrosion tests

IV. Test results

V. Discussion of results _._. 207

VI. Summary

VII. References

\section{INTRODUCTION}

The National Bureau of Standards received in August 1940 a number of samples of bridge wire taken from the cables of the General U. S. Grant Suspension Bridge over the Ohio River at Portsmouth, Ohio. These cables were $7 \frac{1}{8}$ in. in diameter under the wrapping, and each was made up of 1,458 ungalvanized wires of No. 8 gage in three parallelwire strands. The choice of ungalvanized wire was based on the previous satisfactory performance of similar wires in other bridges over periods of 20 to 50 years' service [1] ${ }^{1}$.

After about 12 years of service a number of breaks were discovered in the Portsmouth bridge cables, most of them at the anchorage shoes, and they were replaced by cables made up of galvanized wire. [2]

Some of the broken and unbroken wires from the old cables had previously been subjected to tensile tests and microscopic examination at the Carnegie Institute of Technology. [3] In this report it was concluded that "on the basis of these tests on samples submitted . . . the wire, where not corroded should be satisfactory for this service."

"Of the corroded specimens examined, only those at the anchorage shoes seem dangerously brittle. At these locations, the wire appears

\footnotetext{
${ }_{1}$ Figures in brackets indicate the literature references at the end of this paper.
} 
to have been subjected to a combination of stress and corrosion, resulting in stress-corrosion cracks. Specimens from other locations, in spite of corrosion, seem as yet to have suffered no important deterioration in mechanical properties; these latter tests have not been extensive."

The purpose of the present investigation was so make tests supplementary to these and, particularly, to attempt to produce experimentally stress-corrosion breaks in the wire similar to those that had occurred in service.

An example of a typical service break is shown in figure 1. The course of most of the fractures was transverse to the axis of the wire for a comparatively short distance and then showed a decided tendency to become diagonal. Figures 2 and 3 show some of the stresscorrosion cracks found near service fractures in the wire, as received. All of the cracks observed occurred in the concave side of the curvature of the wire. This side would be under tension if the wire were straightened out in a cable. The cracks, like the service fractures, were transverse for short distances and then tended to become diagonal.

\section{MATERIALS}

Twenty samples of the Portsmouth bridge wire, totalling about 86 feet in length, were submitted. The locations of the samples as removed from the cables are given in table 1 . The wire was 0.162 in. in diameter, ungalvanized, and had been cold-drawn to a specified minimum tensile strength of $220,000 \mathrm{lb} / \mathrm{in}^{2}$.

TABLE 1.-Locations of samples of wire as removed from the cables

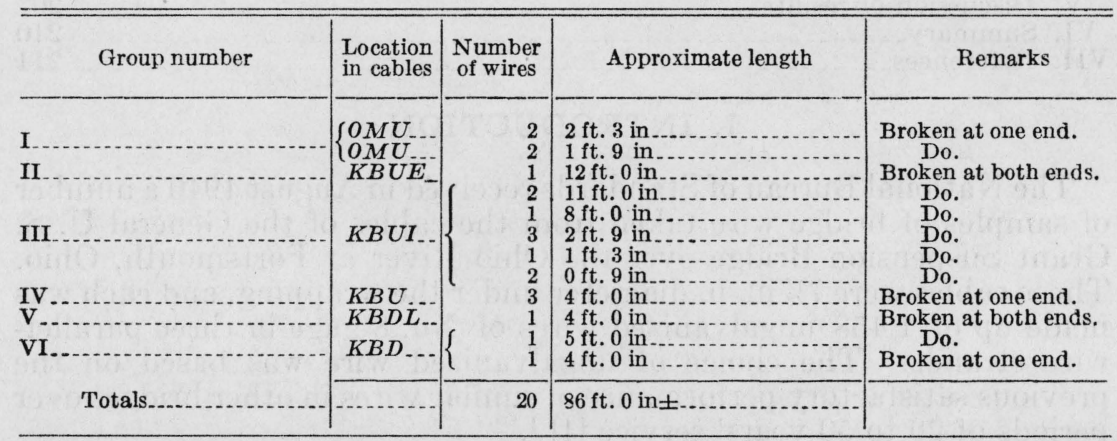

$O$, Ohio end; $K$, Kentucky end; $M$, main span; $B$, backstay; $U$, upstream; $D$, downstream; $E$, exterior strand; $I$, interior strand; $L$, lower strand.

The range of composition reported by the Carnegie Institute of Technology is given in table 2. This table also gives the results of analysis of a sample wire of group III, table 1, submitted to the National Bureau of Standards.

Several years ago an investigation of the failure of the heat-treated Mt. Hope Bridge cable wire was made at this Bureau by Swanger and Wohlgemuth [4]. Tests were also made on samples of the cold-drawn wire used to replace the heat-treated wire in the Mt. Hope Bridge cables. Both the original and the replacement wires were hot-dip galvanized. A few samples of both materials were included in the tests, either 
stripped or as galvanized, for comparsion with the ungalvanized, cold-drawn Portsmouth Bridge cable wire. The compositions of the Mt. Hope materials are included in table 2.

TABLE 2.-Composition of materials

\begin{tabular}{|c|c|c|c|c|c|c|}
\hline \multirow{2}{*}{ Material } & \multicolumn{6}{|c|}{ Composition } \\
\hline & C & Mn & $\mathrm{P}$ & $\mathrm{s}$ & $\mathrm{Si}$ & \\
\hline $\begin{array}{l}\text { Portsmouth (range of four analy- } \\
\text { ses reported by Carnegie In- } \\
\text { stitute of Technology). }\end{array}$ & $\begin{array}{c}\% \\
0.69 \text { to } 0.84\end{array}$ & $\begin{array}{c}\% \\
0.56 \text { to } 0.81\end{array}$ & $\begin{array}{c}\% \\
0.008 \text { to } \\
0.014\end{array}$ & 0.031 to 0.037 & $\begin{array}{c}\% \\
0.03 \text { to }\end{array}$ & 0.14 \\
\hline $\begin{array}{l}\text { Portsmouth (sample from group } \\
\text { III, table 1, submitted to Na- } \\
\text { tional Bureau of Standards). }\end{array}$ & .83 & .53 & .008 & .029 & & .14 \\
\hline $\begin{array}{l}\text { Mt. Hope, heat-treated (Speci- } \\
\text { fication requirements). }\end{array}$ & .70 to .80 & .40 to .60 & & & .12 to & .20 \\
\hline Mt Hope, cold-drawn & .67 & .61 & .025 & .036 & & .15 \\
\hline
\end{tabular}

All of the samples of the Portsmouth wire, as received, had assumed a curvature which presumably was approximately that to which it had been coiled in the mill. The radius of curvature varied from 10.0 to 12.3 in.

The heat-treated Mt. Hope wire was practically straight, while the radius of curvature of the cold-drawn replacement wire of the Mt. Hope Bridge varied from 23.1 to 24.8 in.

Because of the limited amount of material available, no tensile tests were made. The tensile properties previously reported $[3,4]$ for the materials are given in table 3 .

TABLE 3.-Tensile properties of materials as reported in references [3] and [4]

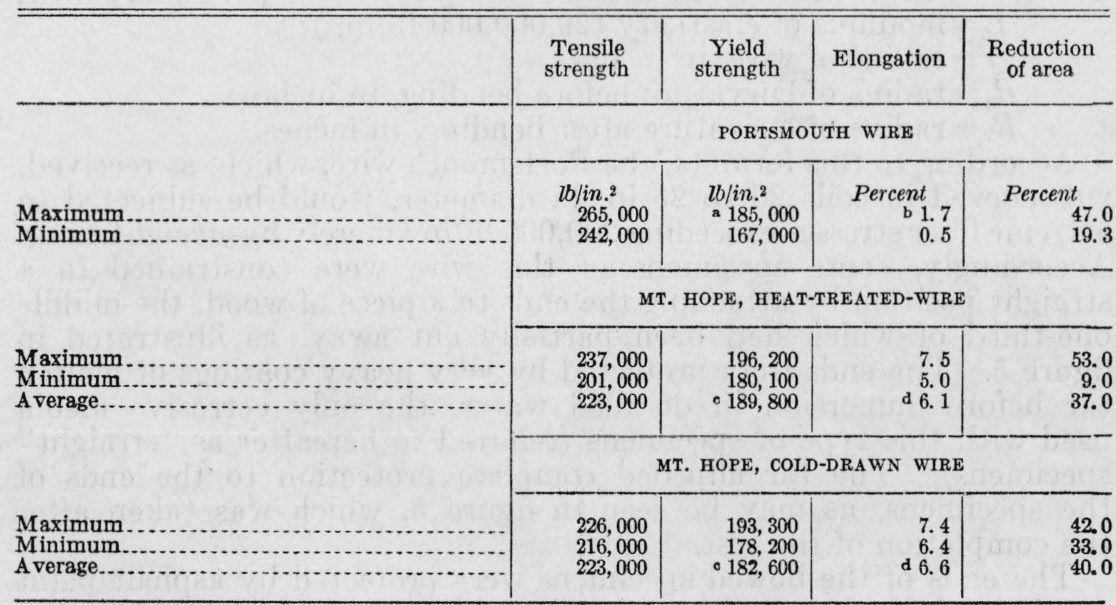

- Stress required to produce extension of 0.75 percent.

b 10-in. gage length.

- Stress required to produce extension of 0.7 percent.

d 4-in. gage length. 


\section{STRESS-CORROSION TESTS}

Stressed specimens of the several materials were subjected to corrosion by immersion in distilled water and approximately $0.01 \mathrm{~N}$ solutions of ammonium nitrate, ammonium nitrite, sodium hydroxide, ammonium sulfate and sodium nitrate. These solutions were selected because of their possible occurrence in the rain or ground waters to which parts of the bridge cables may have been exposed in service. The concentrations used, corresponding to 640 to 850 parts per million, were considerably higher than those usually encountered in rain or in ground waters. It is possible, however, that solutions of comparable concentration could be built up by evaporation of moisture from weaker solutions trapped in anchorage pits or within the cable coverings. The solutions were renewed once a week. During the week the volume of each solution usually was reduced by 10 to 20 percent, depending on the weather. The concentration of the solution, of course, varied inversely as the volume during this time.

Specimens of the several bridge-cable wire materials were statically stressed by changing the curvature of the wire. In most cases the specimens were bent to smaller radii calculated to produce stresses of given magnitudes and held in that position, as illustrated in figure 4 . By twisting the loop of small wire around the ends of the bridge wire, the length of the chord could be reduced to the calculated dimension within the accuracy of measurement-about 0.1 in. Specimens of this type are referred to in this report as "bowed" specimens.

The change in extreme fiber stress produced by changing the curvature of the wire was calculated by use of the formula

where

$$
S=\operatorname{Er}\left(1 / R_{2}-1 / R_{1}\right),
$$

$S=$ maximum change in fiber stress in pounds per square inch;

$E=$ modulus of elasticity $\left(29,000,000 \mathrm{lb} / \mathrm{in} .^{2}\right)$;

$r=$ radius of wire, in inches.

$R_{1}=$ radius of curvature before bending, in inches.

$R_{2}=$ radius of curvature after bending, in inches.

According to this formula, the Portsmouth wire, which, as received, was curved in coils 20 to 25 in. in diameter, would be subjected to extreme fiber stresses exceeding $200,000 \mathrm{lb} / \mathrm{in}^{2}{ }^{2}$ merely by straightening. Accordingly, some specimens of this wire were constrained in a straight position by attaching the ends to a piece of wood, the middle one-third of which had been partially cut away, as illustrated in figure 5. The ends were protected by very heavy coatings of molten tar before immersion in distilled water, the only corrosive media used with this type of specimens (referred to hereafter as "straight" specimens). The tar afforded complete protection to the ends of the specimens, as may be seen in figure 5 , which was taken after the completion of the test.

The ends of the bowed specimens were protected by asphalt paint to about 1 in. below the water line during immersion. However, the paint blistered and peeled off rapidly near the water line, and it was necessary to repaint these areas after a few months. 


\section{TEST RESULTS}

A tabulation of the specimens used, the maximum stresses to which they were subjected, the solutions employed, the exposure period and a brief summary of the test results are given in table 4 .

TABLE 4.-Conditions of stress-corrosion tests of bridge-cable wire

\begin{tabular}{|c|c|c|c|c|c|}
\hline $\begin{array}{c}\text { Specimen } \\
\text { designation }\end{array}$ & $\begin{array}{l}\text { Source of bridge-cable } \\
\text { wire }\end{array}$ & $\begin{array}{l}\text { Approx- } \\
\text { imate } \\
\text { stress }\end{array}$ & Corrosive medium & $\begin{array}{c}\text { Expo- } \\
\text { sure } \\
\text { period }\end{array}$ & Remarks \\
\hline & Portsmouth & $\begin{array}{l}l b / \text { in } .^{2} \\
146,000\end{array}$ & Distilled water- & $\begin{array}{c}\text { Months } \\
40\end{array}$ & Severe \\
\hline & 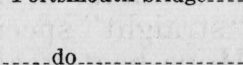 & 164,000 & & to & $\begin{array}{l}\text { no stress-corrosion cracks, } \\
\text { no failures. } \\
\text { Do. }\end{array}$ \\
\hline &..$--d c$ & 190,000 & do & 40 & Do. \\
\hline & Mt. & $\begin{array}{l}196,000 \\
182,000\end{array}$ & $\begin{array}{l}\text { do } \\
\text { do }\end{array}$ & $\begin{array}{l}40 \\
40\end{array}$ & $\begin{array}{l}\text { Do. } \\
\text { Do. }\end{array}$ \\
\hline & (heat-t & 102,000 & & & \\
\hline & $\mathrm{Mt}$ H & $\begin{array}{l}178,000 \\
183,000\end{array}$ & $\ldots d$ & $\begin{array}{l}40 \\
40\end{array}$ & $\begin{array}{l}\text { Do. } \\
\text { Do. }\end{array}$ \\
\hline+7 & (c) & 182,000 & .do. & 40 & Do. \\
\hline & Port: & & $-d$ & 40 & Do. \\
\hline & 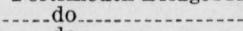 & 214 , & $-\ldots d d$ & 40 & Do. \\
\hline & -...- & & $\ldots . . . d$ & 40 & Do. \\
\hline $5 \ldots$ & 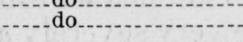 & 144,000 & $0.01 \mathrm{~N} \mathrm{NH}_{4} \mathrm{NO}_{3}$ & 8 & Cracks, 6 months; failed, \\
\hline 6. & ..... do & 165,000 & $.01 \mathrm{~N} \mathrm{NH}_{4} \mathrm{NO}_{3}$ & 7 & Cracks, 6 months; failed, \\
\hline 7. & .....do & 185,000 & $.01 \mathrm{~N} \mathrm{NH}_{4} \mathrm{NO}_{3}$ & 7 & Cracks, 6 months; failed, \\
\hline & d & 199,000 & $.01 \mathrm{~N} \mathrm{NH}_{4} \mathrm{NO}_{3}$ & $61 / 2$ & Cracks, 6 months; failed, \\
\hline \& $\mathrm{H} 2$ & Mt. $\mathrm{Ho}$ & 183,000 & $.01 \mathrm{~N} \mathrm{NH}_{4} \mathrm{NO}_{3}$ & 5 & Cracks, $31 / 2$ months; failed, \\
\hline s $\mathrm{H}$ & (ne & 184,000 & $.01 \mathrm{~N} \mathrm{NH}_{4} \mathrm{NO}$ & $391 / 2$ & Severe localized pitting, no \\
\hline 9 & Portsmouth bri & 144,000 & $.01 \mathrm{~N} \mathrm{NH}_{4} \mathrm{NO}_{2}$ & 31 & Practically no corrosive \\
\hline & & & & & cause of difficulty in ob- \\
\hline & $\ldots$....d & 162,000 & $.01 N$ & 31 & $\begin{array}{l}\mathrm{NH}_{4} \mathrm{~N} \\
\text { Do. }\end{array}$ \\
\hline & t $+2+2$ & & & & \\
\hline & d d & 2 & .011 & 3 & Do. \\
\hline 1 & $\ldots d$ & 150,000 & $.01 \mathrm{~N}$ & 36 & $\begin{array}{l}\text { Practically no corrosive } \\
\text { attack; no cracks, no } \\
\text { failures. }\end{array}$ \\
\hline & - & & & 36 & Do. \\
\hline & - & & & 36 & Do. \\
\hline & $\ldots$ & 149,000 & $.01 \mathrm{~N}(\mathrm{NH}$ & $\begin{array}{l}36 \\
31\end{array}$ & $\begin{array}{l}\text { Do. } \\
\text { Remarkably uniform cor- }\end{array}$ \\
\hline & & & & & $\begin{array}{l}\text { rosive attack, no cracks, } \\
\text { no failures }\end{array}$ \\
\hline & $\ldots$ & 163 & & 31 & \\
\hline & 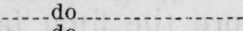 & & & 01 & \\
\hline & 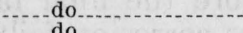 & 20 & .0 & 31 & Do. \\
\hline & & & & & cracks. \\
\hline 22 & $\ldots \ldots d$ & 163,000 & $.01 \mathrm{~N} \mathrm{NaI}$ & 7 & Cracks, 3 months; failed, \\
\hline 23 & $A 0$ & 182,000 & $.01 \mathrm{~N} \mathrm{NaNO}_{3}$ & $31 / 2$ & Cracks, 3 months; failed, \\
\hline & & 207,000 & $.01 \mathrm{~N} \mathrm{NaNO}$ & $31 / 2$ & $21 / 2$ months; failed, \\
\hline & do & 140,000 & $.01 \mathrm{~N} \mathrm{NaN}$ & 4 & Cracks, $31 / 2$ months; failed, \\
\hline 26 & do & 120,000 & $.01 \mathrm{~N} \mathrm{NaNO}_{3-}$ & 9 & $31 / 2$ months; fail ed \\
\hline 27 & do & 100,000 & $.01 \mathrm{~N} \mathrm{NaNO}_{3}$ & 13 & Failed at deep pit, cracks \\
\hline 28 & do & 134,000 & $.01 \mathrm{~N} \mathrm{NH}_{4} \mathrm{~N}$ & 5 & s; failed, \\
\hline 2 & do & 112,000 & $.01 \mathrm{~N} \mathrm{NH}_{4} \mathrm{NO}$ & 4 & Cracks, $31 / 2$ months; failed, \\
\hline & do & 90,000 & $.01 \mathrm{~N} \mathrm{NH}_{4} \mathrm{NC}$ & 19 & Unbroken after 19 months. \\
\hline
\end{tabular}

a Stripped.

b Hot-dip galvanized.

- Straight specimens - all orhers were bowed. 
Further details of the corrosion test results are given below:

Distilled water.-Samples of all the materials were exposed in distilled water. In bowed specimens of Portsmouth wire the stresses ranged from 146,000 to $196,000 \mathrm{lb} / \mathrm{in}^{2}$. No stress-corrosion cracks or failures occurred in these specimens, although after immersion for 40 months, corrosive attack was very severe (fig. 6). The attack was of a localized nature in that rather large irregular areas were corroded more severely than some corresponding adjacent areas. The edges of these areas were very sharply defined, and within them the corroded surfaces were comparatively smooth. In some of these localized areas near the water line the diameter of the wire was reduced nearly 50 percent, that is, to $0.083 \mathrm{in}$. from the original diameter of $0.162 \mathrm{in}$.

The same type of corrosion occurred on the "straight" specimens of Portsmouth wire (fig. 7), on samples of Mt. Hope heat-treated wire (fig. 8), and on Mt. Hope cold-drawn wire (fig. 9) exposed in the bare state. Both the heat-treated and cold-drawn Mt. Hope wires exposed in the hot-dip galvanized condition showed localized pitting after 40 months (figs. 8 and 9).

No stress-corrosion cracks or failures occurred in any of the specimens exposed in distilled water.

Ammonium sulfate.-Bowed specimens of Portsmouth wireimmersed in $0.01 \mathrm{~N}$ ammonium sulfate for 31 months were very severely attacked particularly near the water line, as may be seen in figure 10. In some places the diameter of the wire was reduced 63 percent, from 0.162 to $0.060 \mathrm{in}$. The corrosive attack was remarkably uniform, and the corroded surface was very smooth except near the water line, where slight irregularities occurred. There were no stress-corrosion cracks or failures.

Ammonium nitrite and sodium hydroxide.-Bowed specimens of Portsmouth wire were exposed in $0.01 \mathrm{~N}$ solutions of ammonium nitrite and sodium hydroxide under stresses ranging from 144,000 to $206,000 \mathrm{lb} / \mathrm{in}^{2}$. Both solutions proved to be very good inhibitors in the concentrations used. The specimens showed practically no evidence of corrosion after exposure of 31 months in the nitrite and 36 months in the hydroxide (figs. 11 and 12).

Nitrate solutions.-Of the 14 bowed Portsmouth wire specimens immersed in the $0.01 \mathrm{~N}$ solutions of ammonium nitrate and sodium nitrate, 11 developed stress-corrosion cracks and failed, apparently as a direct result of such cracking after exposures ranging from $3 \frac{1}{2}$ to $9 \frac{1}{2}$ months. The appearance of such cracks before the finai failure is shown in figure 13. Examples of typical stress-corrosion failures are shown in figures 14 and 15 . Longitudinal sections containing stresscorrosion cracks located near the fractures are shown in figures 16 and 17 and at higher magnification in figures 18 and 19.

As may be seen by comparison of these figures with figures 1, 2, and 3 , the cracks and fractures produced in these solutions were similar to those which occurred in service. In most cases the course of both cracks and fractures was transverse for a short distance and then became diagonal. Many of the cracks branched longitudinally in two directions. Most of the cracks were quite wide at the top and were filled with corrosion product. It was not readily apparent, therefore, whether they were transcrystalline or intercrystalline in these regions. In the innermost narrower parts, however, particularly after they had assumed a diagonal course, they were definitely intercrystalline in nature, as shown in figure 20. 
In most cases the cracks produced in the laboratory tests were located on the convex side of the bowed specimens, as would be expected since this side was in tension. In two instances, however, cracks were also found on the concave, or compression, side of the bowed specimens. One of these cracks is shown in figure 21. It is possible that these cracks had already occurred in service when this part of the wire was in tension and were present in the wire as received.

Two of the 14 bowed specimens immersed in the nitrate solutions failed at exceptionally deep pits on the compression side of the wire. One of these failures is shown in figure 22. Other parts of the same wire showed no evidence of severe pitting. A section through the pit is shown in figure 23. This specimen also contained stress-corrosion cracks on the tension side near the pit, as shown in figure 24. The pit evidently developed faster than the cracks, however, and the final failure occurred at the pit. No stress-corrosion cracks were found on the other specimen that failed at a similar pit.

Only 1 of the 14 bowed specimens of Portsmouth wire exposed in the nitrate solutions did not fail, either by stress-corrosion or because of exceptionally severe localized pitting. This specimen, under a static stress of $90,000 \mathrm{lb} / \mathrm{in}^{2}$, the lowest used, was immersed for 19 months in $0.01 \mathrm{~N}$ ammonium nitrate solution without failure. At the end of this period the specimen showed little evidence of corrosive attack in the central portion and only slight localized pitting near the water line (fig. 25).

One bowed specimen of the Mt. Hope heat-treated wire (stripped) and a similar one of the cold-drawn replacement wire (also stripped) were tested in the $0.01 \mathrm{~N}$ ammonium nitrate solution. The colddrawn wire did not fail after 391/2 months' exposure. Severe localized pitting developed near the water line, but very little corrosive attack occurred in the central portion, and there was no evidence of stress-corrosion cracks. The heat-treated wire, on the other hand, developed numerous stress-corrosion cracks after $3 \frac{11}{2}$ months and failed after 5 months' exposure. This fracture was transverse all the way across the wire as shown in figure 26 . Longitudinal sections through some of the cracks near the fracture are shown in figures 27 , 28 , and 29. The intercrystalline course of one of the cracks, particularly in its innermost part, is clearly revealed in these figures.

\section{DISCUSSION OF RESULTS}

The results of the laboratory tests strongly support the tentative conclusion expressed in the report of the Carnegie Institute of Technology, that the service failures of the Portsmouth Bridge wires were due to the combined effects of stress and corrosion. The possibility of parts of the cables having been exposed to the attack of nitrate solutions of concentrations comparable to those used in the laboratory tests has been pointed out, and the results of these tests show that failures can be caused by the corrosive action of such solutions in combination with imposed stresses much lower than would be produced merely by straightening the wire.

Intercrystalline cracks may be developed in many metals and alloys under certain corrosive conditions or under the combined effects of stress and corrosion. Some metals such as certain aluminum alloys and stainless steel may be subject to intercrystalline corrosion without 
the application of stress. On carbon steels the intercrystalline type of corrosive attack usually is produced only when the material is subjected to stress, either imposed or residual. Smialowski [5] has recently reported, however, that intercrystalline penetration was obtained in the absence of mechanical stress in a coarse-grained soft iron which had been stress-relieved at $850^{\circ} \mathrm{C}$. After 8 hours in a boiling 50-percent solution of ammonium nitrate, it became so brittle that it disintegrated into individual grains when bent.

Many reports have appeared in the literature on investigations of the intercrystalline cracking of boiler plate and also on the occurrence of similar failures in evaporators and other steel structures subjected under stress to the corrosive action of hot, concentrated nitrate solutions.

Many investigators consider the "caustic embrittlement" of steam boilers to be caused by stress-corrosion. Zappfe [6], however, believes that such embrittlement is due to hydrogen. Whether or not stress-corrosion is involved in the actual service failures of boilers, the production in the laboratory of intercrystalline stress-corrosion cracks in boiler plate steel has been reported many times. The results of some of the most recent investigations indicate that the occurrence of such cracks is influenced by three principal factors: (1) the composition and corrosive action of the corrosive medium; (2) the presence of stress, either imposed or residual; and (3) the composition and structural condition of the steel.

Schroeder and his coworkers $[7,8,9,10,11]$ produced intercrystalline cracks in statically stressed low-carbon steels in concentrated caustic solutions, particularly those containing small additions of certain oxidizing agents, such as sodium nitrate, potassium permanganate, sodium chromate, lead oxide, and sodium silicate. They advanced the theory that these cracks were produced by the selective corrosive attack of certain solutions which passivate the crystal faces but attack the grain boundaries. They postulate that the atoms at the grain boundaries are acted upon by atomic forces different on one side from those on the other because of the difference in orientation. These atoms, therefore, may be in a strained condition, which is increased when the metal as a whole is under stress. This may cause these atoms to be more easily removed than those in the body of the crystal. If the action of the corrosive medium is too severe, the overall attack obscures the selective action. Severe intercrystalline corrosion occurs when the passivating action of the solution is sufficient to protect the crystal face but not the grain boundaries.

Houdremont, Bennek, and Wentrup [12] tested statically stressed low-carbon steels of various compositions in hot, concentrated solutions containing 30 to 60 percent of calcium nitrate and 3 to 6 percent of ammonium nitrate. From their results they concluded that the production of intercrystalline cracks is strongly influenced by a critical structural condition of the steel, which depends not only on its composition but also on its previous treatment, particularly heating or annealing. They found that susceptibility to intercrystalline cracking decreased with higher carbon and aluminum contents and that completely deoxidized steels had high resistance, whereas steels heated in an atmosphere of nitrogen had low resistance to this type of attack.

It should be pointed out that most of the investigations cited above 
were concerned primarily with the effect of hot, concentrated caustic or nitrate solutions on stressed low-carbon steels, such as would be suitable for boiler plate. Most of the investigators reported no intercrystalline cracking in solutions containing less than 25 to 30 percent of nitrates-usually sodium, ammonium or calcium nitrates or mixtures of these salts.

Very little information is available in the literature concerning the production of intercrystalline cracks in high-carbon steels or by dilute solutions comparable to those used in the present investigation. Schroeder and Berk [11] obtained intercrystalline cracks in statically stressed steel specimens by selective electrolytic corrosive action. The specimens were made anodes in solutions containing as little as a few parts per million of sodium chloride or sodium nitrate. When the current was properly adjusted the only evidence of general corrosion was darkening of the surface, but the specimens were deeply cracked or broken in a few days. They also obtained intercrystalline cracks in stressed steel specimens immersed for a few days in dilute nitric acid solutions containing manganous chloride. They considered that the action of the manganous chloride probably was to catalyze the decomposition of the nitric acid, thus aiding the selective attack.

The results of the present investigation are in line with the selective corrosion theory of intercrystalline attack. No intercrystalline cracks were produced either in the severely corrosive media, distilled water and sodium sulfate or in the completely inhibitive solutions sodium hydroxide and sodium nitritè. In the nitrate solutions the general attack was very slight, but intercrystalline cracks, and occasionally unusually severe and extremely localized pits, were produced. A marked difference was noted in the character of the corrosion products produced in the different solutions, which may have some bearing on the nature of the corrosive attack. In the severely corrosive media large amounts of loose, nonadherent rust was formed, which was easily removed by running tap water or by wiping with a damp cloth. In the nitrate solutions a thin, tightly adherent coating of rust was quickly formed, after which the general corrosive attack, as measured by the further appearance of rust, proceeded very slowly. In the completely inhibitive solutions, very little rust was formed.

Because of the limited amount of material available, it was not possible to determine definitely whether or not there is a lower limit of imposed static stress below which failure of the bridge-wire samples would not occur. At stresses in the neighborhood of the yield strength some of the results were rather erratic, but at lower stresses the time of exposure necessary to cause failure seemed to increase considerably. The lowest stress at which stress-corrosion cracks were obtained within a reasonable length of time was $100,000 \mathrm{lb} / \mathrm{in}^{2}$. It is possible, however, that exposure for longer periods, comparable to those which might occur in service, would cause failure at lower stresses.

It should be pointed out that the stresses discussed above are the nominal static stresses imposed by bending the wire. Because of the difficulty in evaluating the residual stress in a curved wire of small diameter, its possible presence was not taken into account, and therefore the imposed stress may not be the true stress. Cold-drawing operations usually result in residual stresses whose distribution is such

604947-44-5 
that the surface of the drawn wire is in tension. As the Portsmouth wire was not heated after drawing, it is probable that the convex side of the bowed specimens of this material were under some residual tensional stress in addition to the applied stress. In these cases the actual stress, therefore, might be considerably higher than the nominal applied stress. The surface of heat-treated wires might be either in tension or compression, depending on the rate of cooling. As the heat-treated $\mathrm{Mt}$. Hope wire was both tempered and hot-dip galvanized, it would be expected that any residual stress resulting from quenching would be largely relieved. Similarly, hot-dip galvanizing would act as a stress-relieving treatment for the cold-drawn Mt. Hope wire. In these cases it is probable, therefore, that the applied stress was very nearly the true stress.

The same concentration of solution $0.01 \mathrm{~N}$, was used in all the tests. The possible effect of variation in solution concentration on the combined effect of stress and corrosion, therefore, was not determined. Further study of the effect of other corrosive media, particularly dilute sodium chloride solutions, such as might be encountered in marine exposures, would seem to be desirable.

Very little information can be gleaned from the results of the present investigation in regard to the effect of the composition and structural condition of the steel on the formation of stress-corrosion cracks. It is true that of three wire materials of very similar composition, one cold-drawn and one heat-treated developed cracks, whereas the other cold-drawn material did not. However, because of the limited number of specimens, particularly of the two materials last-named, no definite deductions are justified.

It is evident from a comparison of figures 28 to 33 , inclusive, that the microstructures of the materials do not reveal the effect of any differences in composition, fabrication, or heat treatment to which their differences in corrosion behavior could be attributed. Further investigation under better controlled conditions would be necessary to determine the effect of these variables.

\section{SUMMARY}

Static stress-corrosion tests were made on samples of cold-drawn Portsmouth Bridge cable wire and on a few samples of heat-treated Mt. Hope Bridge cable wire and the cold-drawn wire used in the replacement cables of the Mt. Hope Bridge.

Stress-corrosion cracks and failures were produced in nearly all the samples of Portsmouth wire and in one sample of heat-treated Mt. Hope wire by immersion in $0.01 \mathrm{~N}$ solutions of ammonium or sodium nitrate.

The production of these cracks in the laboratory under conditions similar to those which might have existed in service confirms the previous tentative conclusion that service failures of the Portsmouth Bridge wires were due to stress corrosion, and demonstrates the possible manner of their formation.

Stress-corrosion cracks were not produced in more corrosive solutions, such as distilled water or ammonium sulfate, nor in completely inhibitive solutions, such as ammonium nitrite or sodium hydroxide (all solutions $0.01 \mathrm{~N}$ ). The lowest value of imposed stress under which stress-corrosion cracks were found in the Portsmouth wire was 
$100,000 \mathrm{lb} / \mathrm{in}^{2}$. No account was taken, however, of the possible presence of residual stress, and the imposed stress probably was not the true stress.

No stress-corrosion cracks were produced in a statically stressed specimen of cold-drawn $\mathrm{Mt}$. Hope replacement wire exposed in one of the nitrate solutions, although this material was similar in composition and physical properties to the Portsmouth wire.

A more complete study of stress-corrosion cracking in dilute solutions would seem to be desirable, particularly if carried out under conditions where variables such as residual stress could be controlled and the effect of such factors as composition, fabrication, and heat treatment of the steel determined.

\section{REFERENCES}

[1] D. B. Steinman, Ohio River Suspension Bridge at Portsmouth, Eng. NewsRecord 99, 620 (1927).

[2] Anonymous, Bridge recabled after 12 years' service, Eng. News-Record 124, 593 (1940).

[3] Unpublished report of Carnegie Institute of Technology.

[4] W. H. Swanger and G. F. Wohlgemuth, $r$ ailure of heat-treated wire in bridge cables, Proc. Am. Soc. Testing Materials 36, Pt. 2, 21 (1936).

[5] M. Smialowski, Beitrag zur Kenntnis der interkristallinen Korrosion von Weicheisen in Ammoniumnitralosung, Korrosion u. Metallschutz 15, 81 (1939).

[6] C. A. Zapffe, Boiler Embrittlement, Trans. Am. Soc. Mech. Engrs. 66, 81 (1944).

[7] W. C. Schroeder and A. A. Berk, Action of solutions of sodium silicate and sodium hydroxide at $250^{\circ} \mathrm{C}$ on steel under stress, Metals Tech. Pub. 691 (Jan. 1936).

[8] A. A. Berk and W. C. Schroeder, Apparent correlation between the over-all reaction of solutions on steel and the embrittlement of steel. Paper presented at Am. Soc. Mech. Engrs. Boiler Feed Water Session (1936).

[9] W. C. Schroeder, A. A. Berk, and E. P. Patridge, Effect of solution compostion on the failure of boiler steel under static stress at $250^{\circ} \mathrm{C}$. Proc. Am. Soc. Testing Materials 36 pt. 2, 721 (1936).

[10] W. C. Schroeder, A. A. Berk, and R. A. O'Brien, Intercrystalline cracking of steel in aqueous solutions, Metals \& Alloys 8, 320 (1937).

[11] W. C. Schroeder and A. A. Berk, Intercrystalline cracking of boiler steel and its prevention. Bureau of Mines Bul. 443 (1941).

[12] E. Houndremont, H. Bennek, and H. Wentrup, Erforschung und Bekämpfung der interkristallinen Korrosion des unlegierten Stahlen, Stahl u. Eisen 35, 757-763, 791-801 (1940).

Washington, June 12, 1944. 


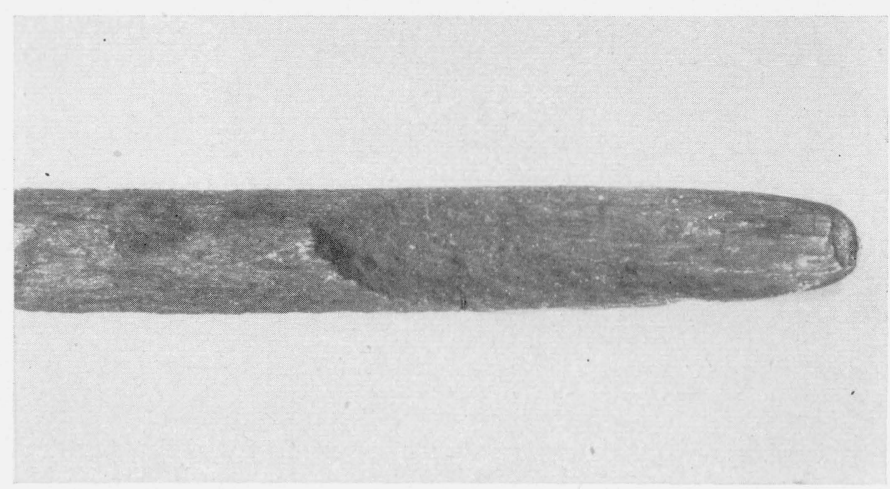

Figure 1.-Example of service fracture of Portsmouth bridge wire, as received. Broken end of wire from group III, table $2 ; \times 3$.

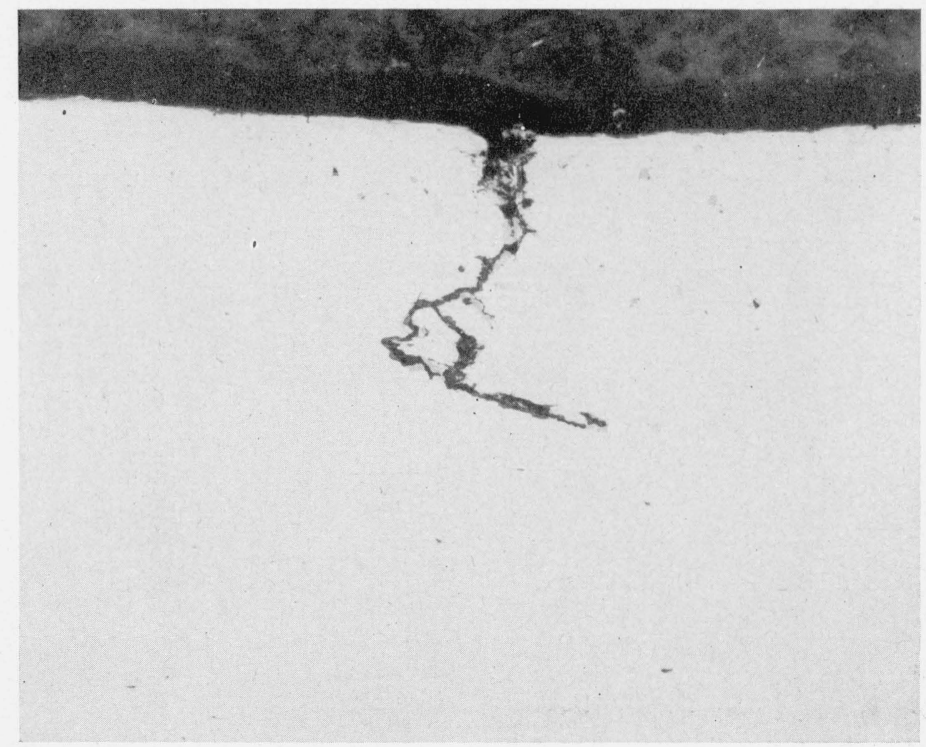

Figure 2.-Stress-corrosion crack near service fracture of Portsmouth bridge wire. Longitudinal section, as received. Unetched; $\times 100$. 


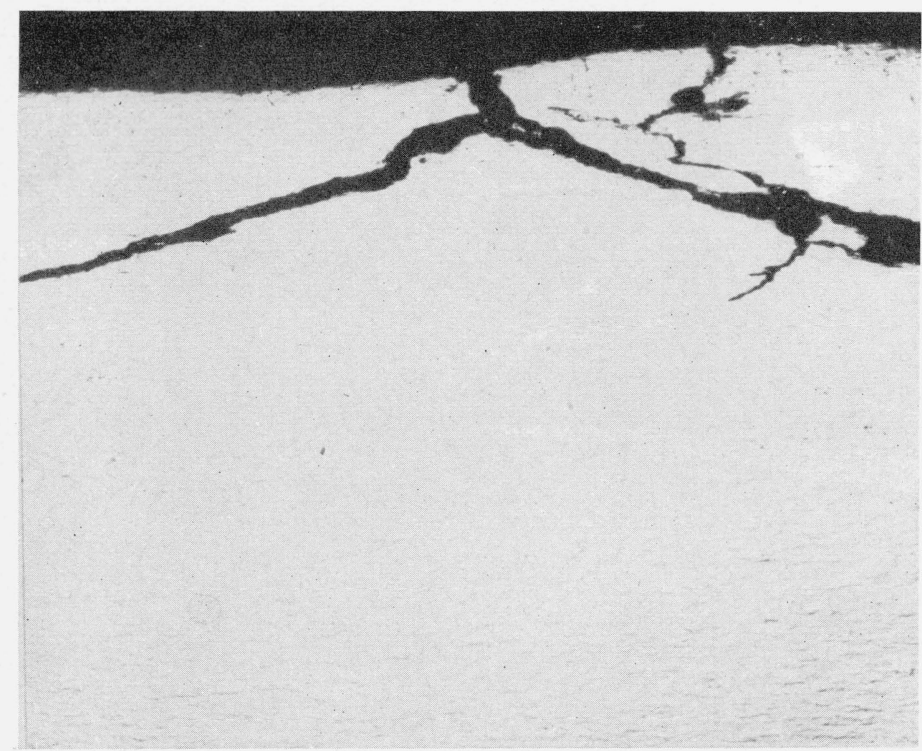

Figure 3.-Stress-corrosion cracks near fracture of Portsmouth bridge wire. Longitudinal section, as received. Unetched; $\times 100$.

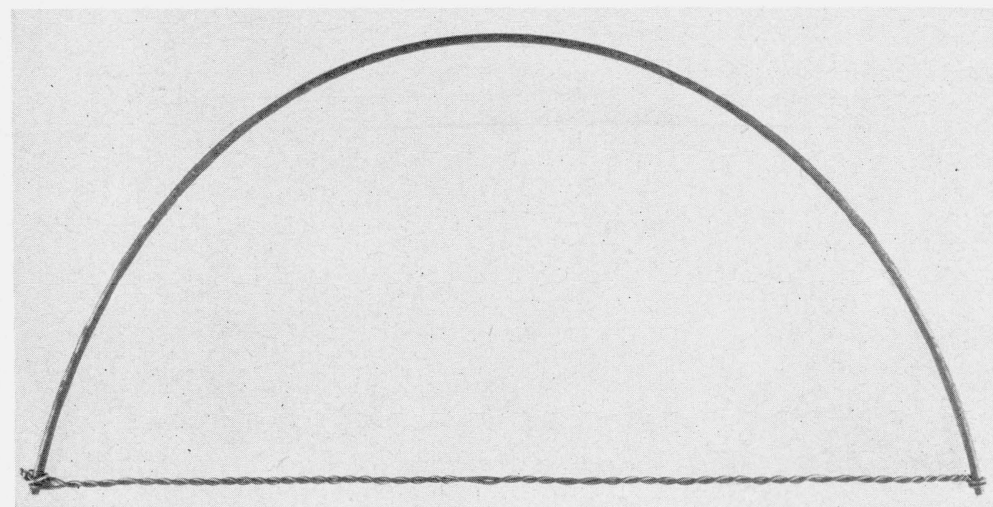

FIGURE 4.-Example of "bowed" bridge wire specimens tested under static stress in various corrosive media; $\times 1 / 4$. 

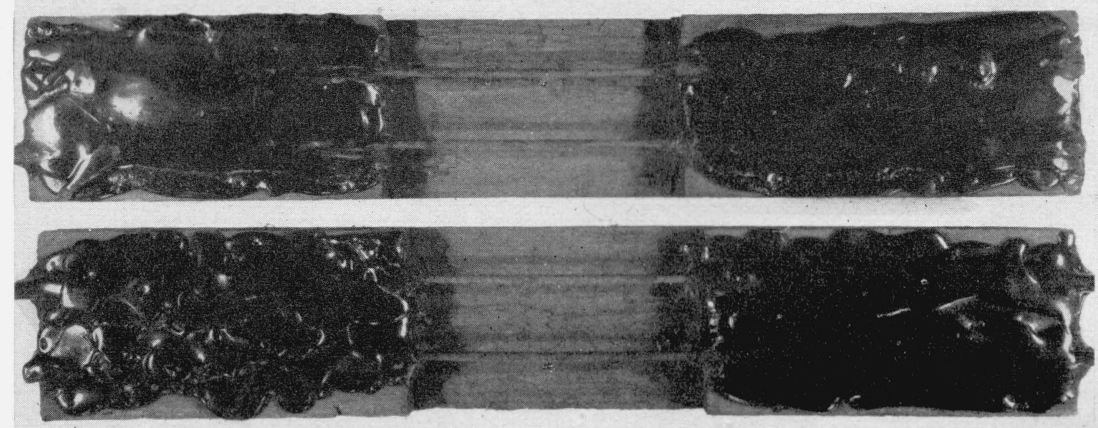

FiguRE 5.-Example of "straight" specimens of bridge wire tested under static stress, in distilled water; $\times 1 / 4$.

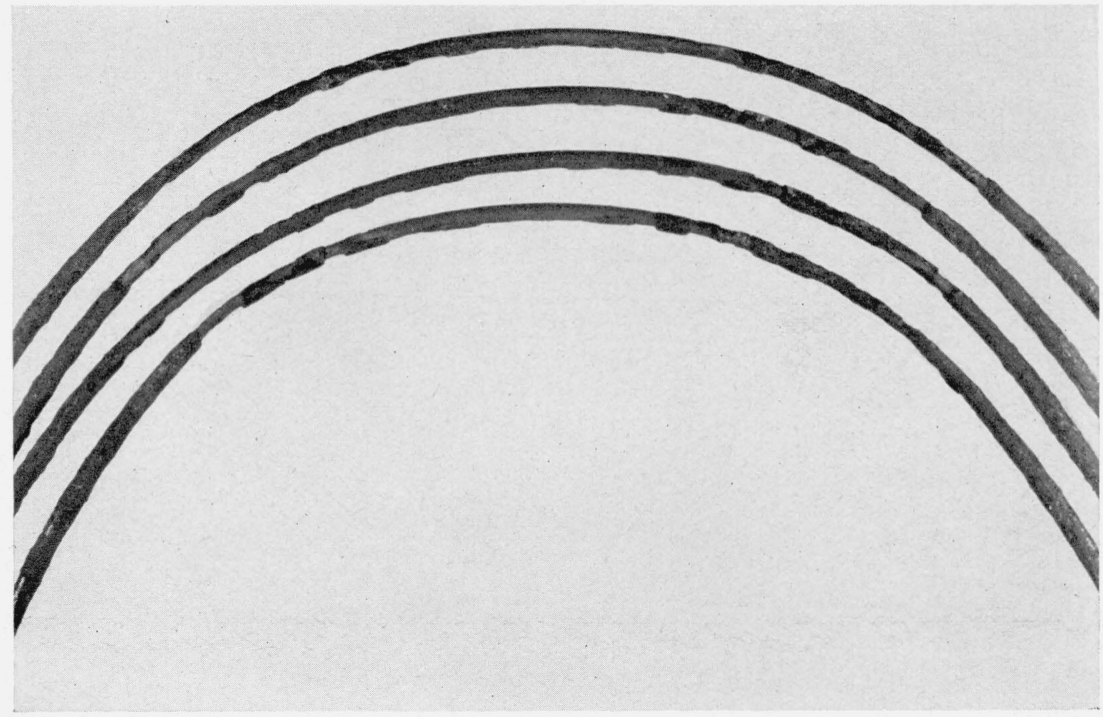

Figure 6._ "Bowed" specimen of Portsmouth bridge wire after immersion for 40 months in distilled water. Note the severe, nonuniform corrosive attack. The specimens were designated $1,2,3$, and 4 from top to
bottom; $\times 1 / 2$. 


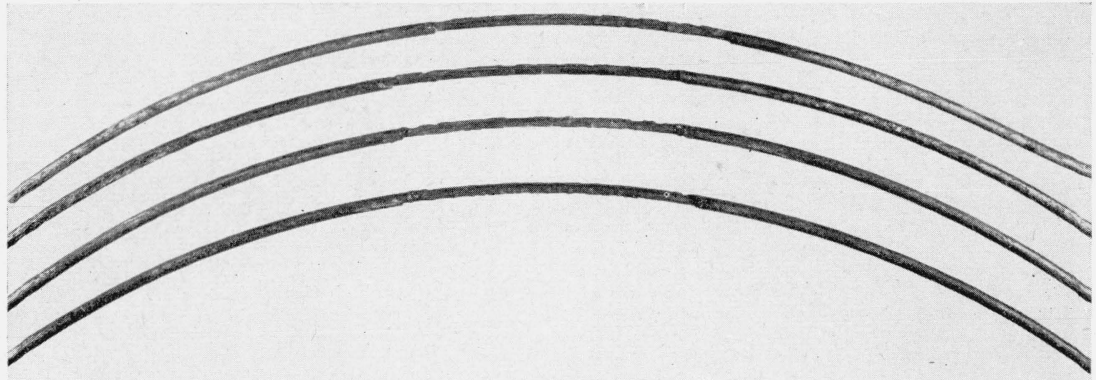

FiguRe 7.- "Straight" specimens of Portsmouth bridge wire after immersion for 40 months in distilled water.

The corrosive attack was severe and nonuniform. The specimens were designated S1, S2, S3, and S4 from top to bottom; $\times 1$.

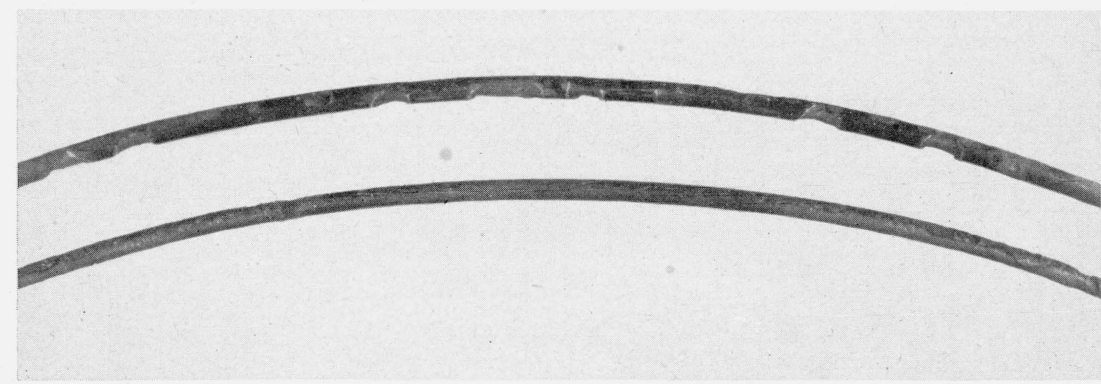

Figure 8.- "Bowed" specimens of heat-treated Mt. Hope bridge wire after immersion for 40 months in distilled water.

Note the severe, nonuniform, corrosive attack. Specimen 3, top, was hot-dip galvanized. Specimen No. 1 , bottom, was stripped; $\times 1 / 2$.

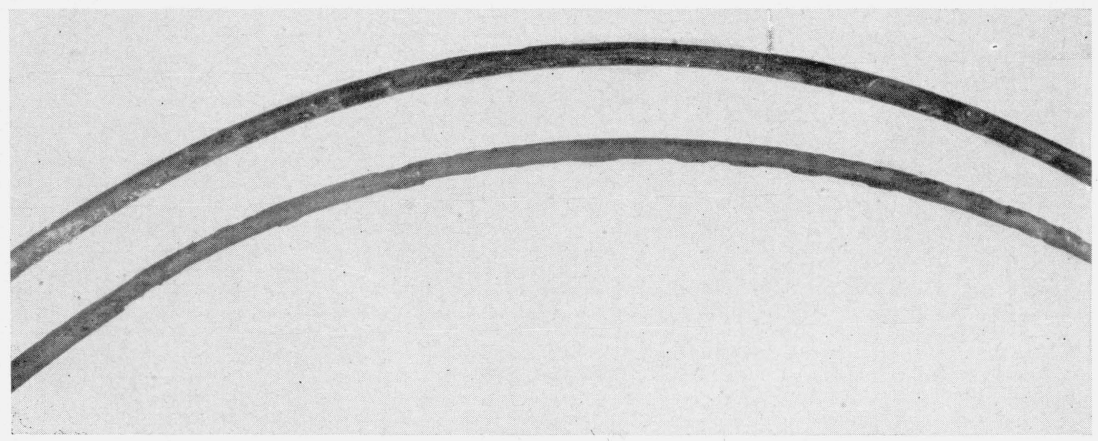

Figure 9.- "Bowed" specimens of cold-drawn Mt. Hope bridge wire after immersion for 40 months in distilled water.

Note the severe, nonuniform corrosive attack. Specimen 7 , top, was hot-dip galvanized. Specimen 5 , bottom, was stripped; $\times 1 / 2$. 


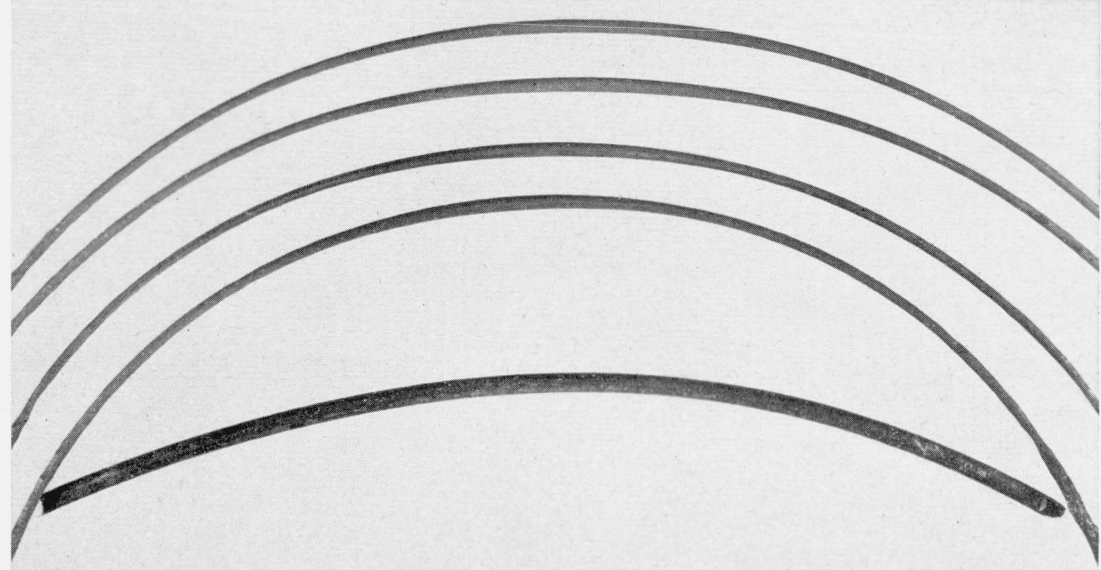

Figure 10.- "Bowed" specimens (Nos. 1\%, 18, 19, 20, top to bottom) of Portsmouth bridge wire after immersion for 31 months in a $0.01 \mathrm{~N}$ solution of ammonium sulfate.

The corrosive attack was severe but very uniform. A sample of the wire as received is shown below to demonstrate the reduction in diameter due to corrosion; $\times 1 / 2$

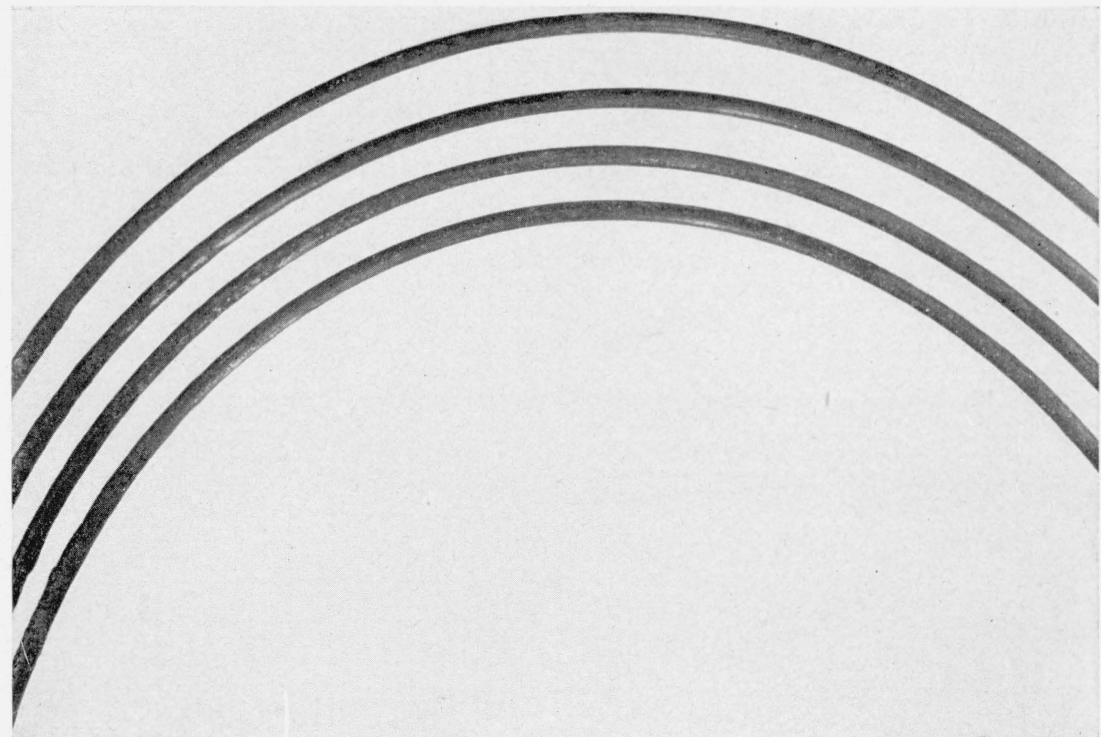

Figure 11.- "Bowed" specimens (Nos. 9, 10, 11, 12, top to botiom) of Portsmouth bridge wire after immersion for 31 months in a $0.01 \mathrm{~N}$ solution of ammonium nitrites.

The solution was almost completely inhibitive and the samples show no evidence of corrosive attack; $\times 1 / 2$ 


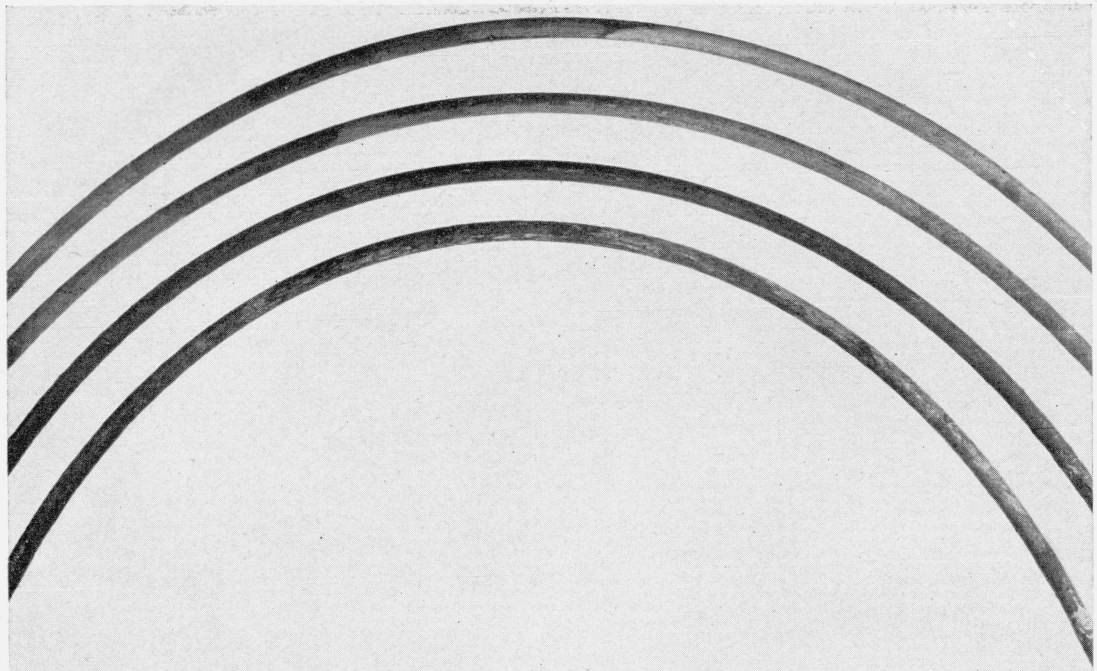

Figure 12.- “Bowed" specimens (Nos. 13, 14, 15, 16, top to bottom) of Portsmouth bridge wire after 36 months' immersion in a $0.01 \mathrm{~N}$ solution of sodium hydroxides.

The samples show no evidence of corrosive attack; $\times 1 / 2$.

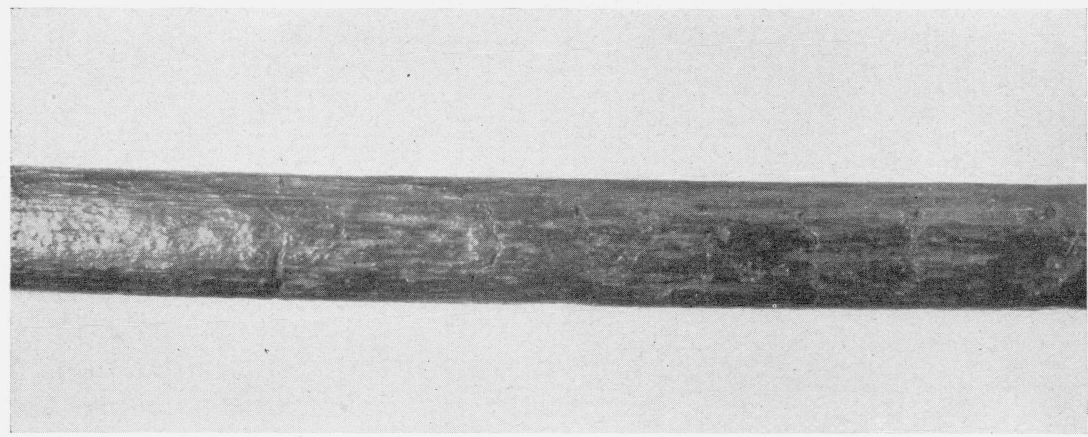

Figure 13.-Appearance of stress-corrosion cracks in a "bowed" specimen (No. 8) of Portsmouth bridge wire prior to failure.

The cracks appeared after 6 months of immersion, under static stress, in a $0.01 \mathrm{~N}$ solution of ammonium nitrate; $\times 3$. 


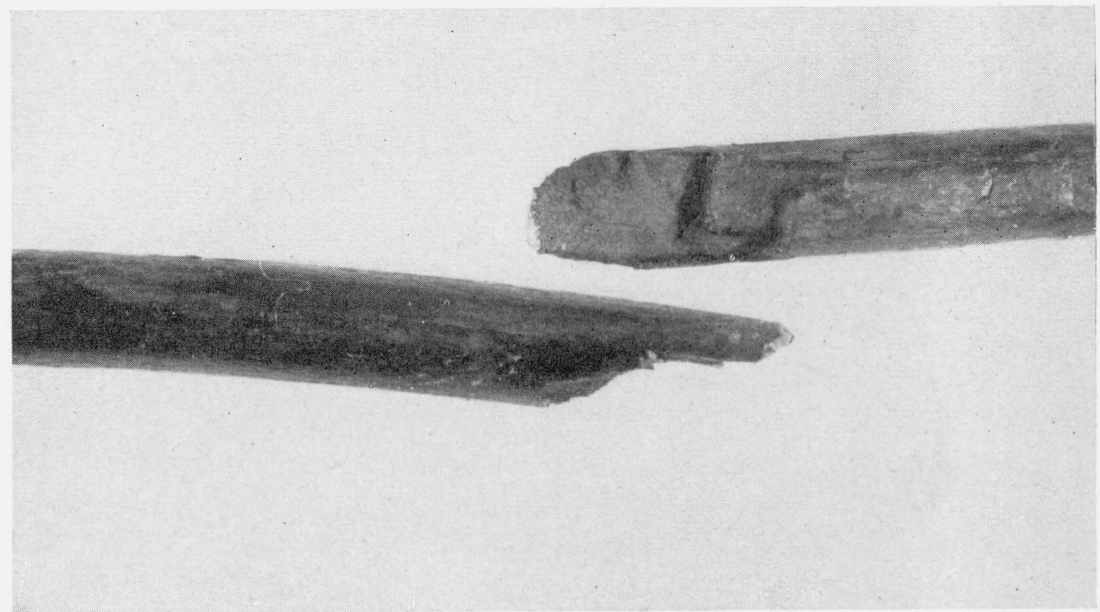

Figure 14.-Appearance of stress-corrosion fracture of "bowed" specimen 8 shown in figure 13 after $6 \frac{1}{2}$ months immersion; $\times 3$.

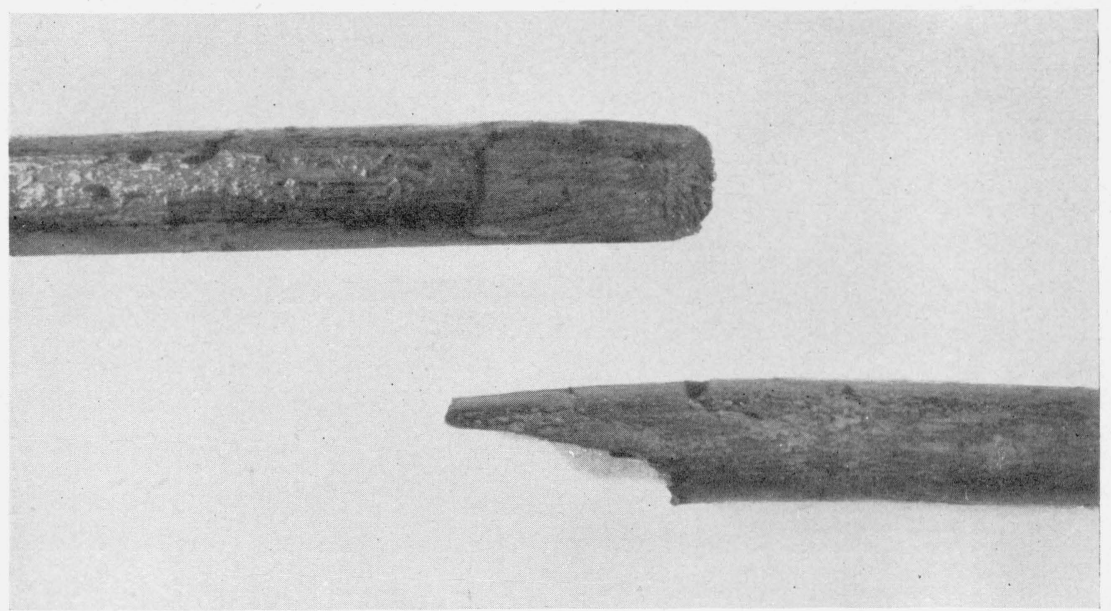

Figure 15.- Stress-corrosion fracture of "bowed" specimen 22 of Portsmouth bridge wire after immersion for 7 months in a $0.01 \mathrm{~N}$ solution of sodium nitrate; $\times 3$. 


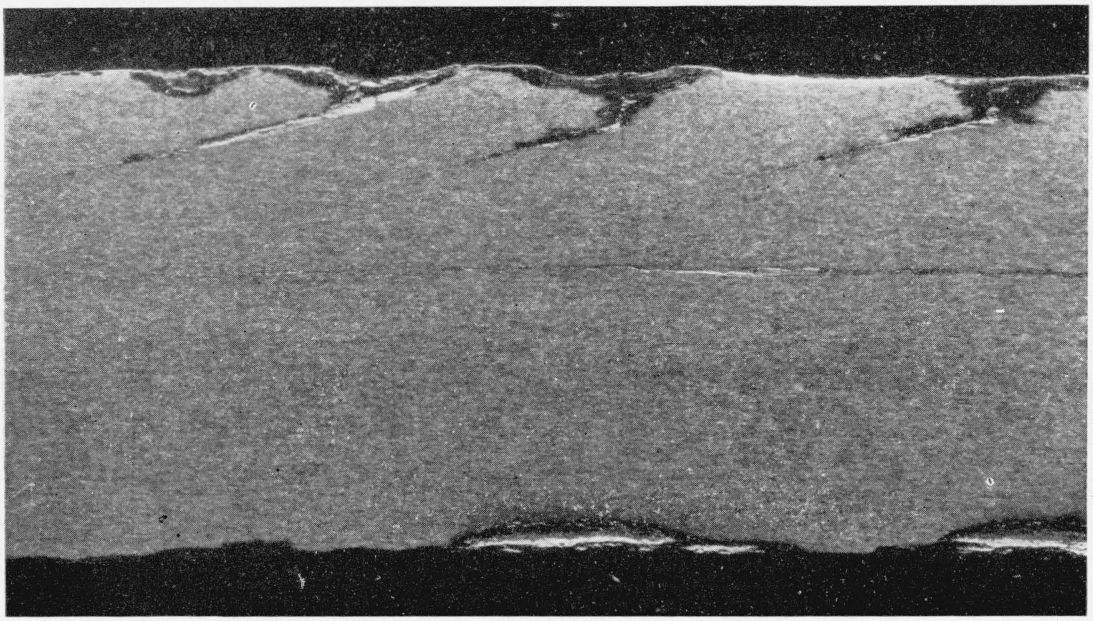

FIGURE 16.-Longitudinal section showing cracks near the stress-corrosion fracture of "bowed" specimen 7 of Portsmouth bridge wire immersed 7 months in a $0.01 \mathrm{~N}$ solution of ammonium nitrate.

Nital etching; $\times 12$.

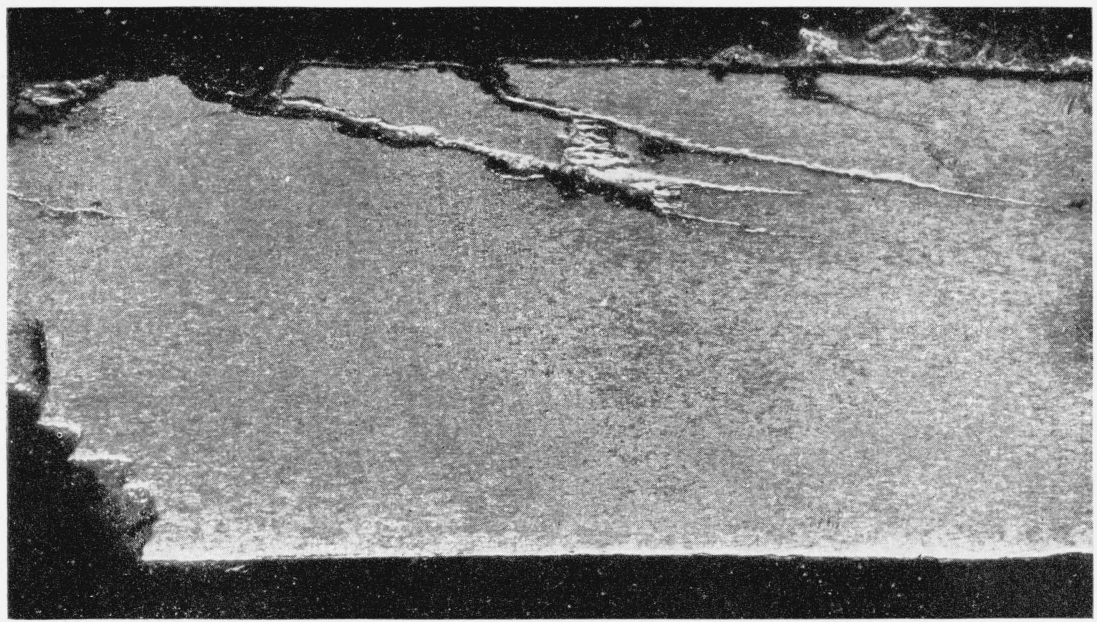

FIGURE 17.-Longitudinal section showing crack near the stress-corrosion fracture of "bowed" specimen 22 of Portsmouih bridge wire immersed 7 months in a $0.01 \mathrm{~N}$ solution of sodium nitrate. 


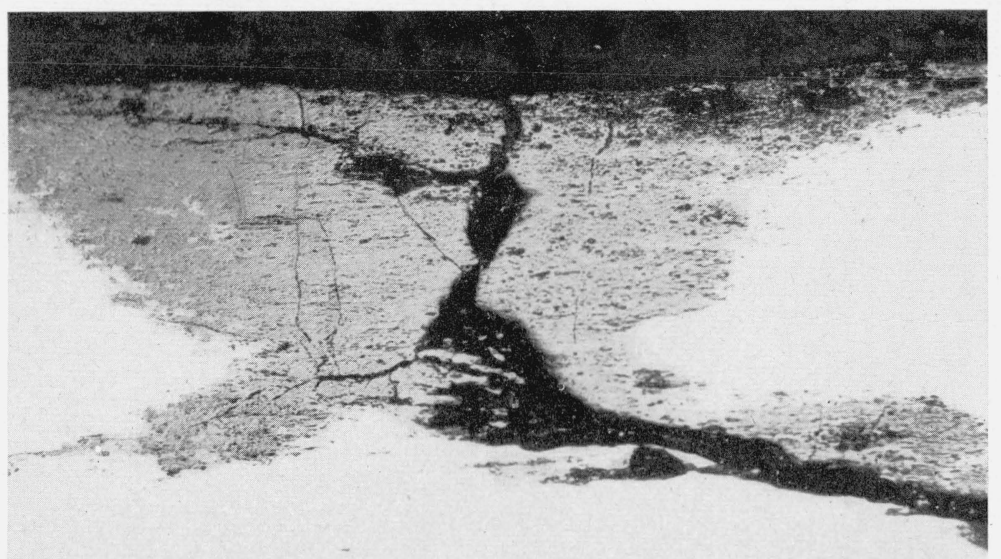

FigURE 18.- One of the cracks of figure 16 at higher magnification. Unetched; $\times 100$.

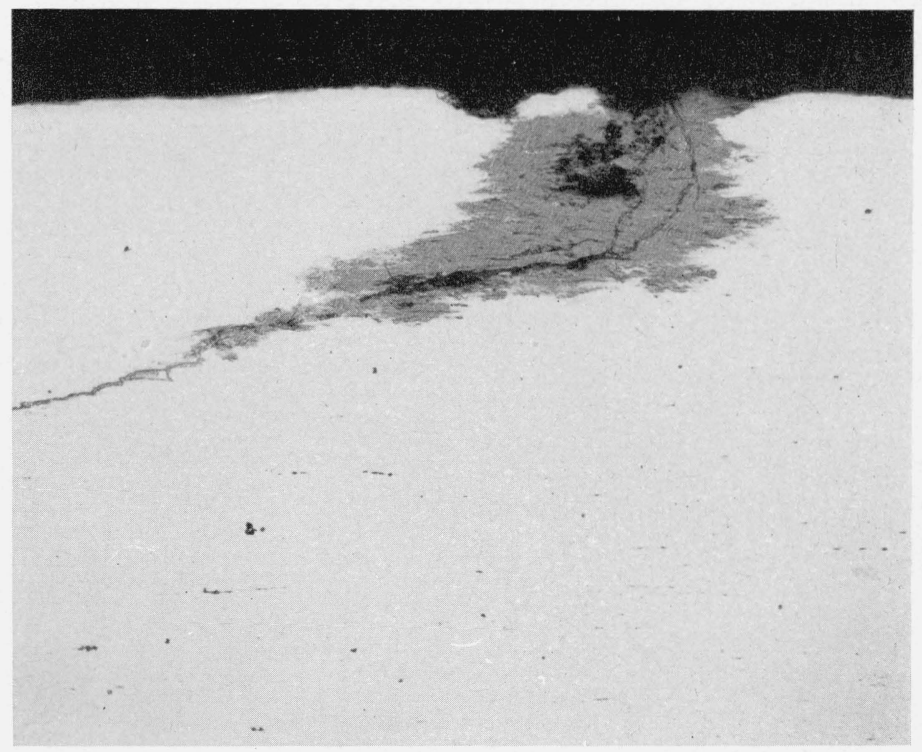

Figure 19.-One of the cracks of figure 17 at higher magnification.

Unetched; $\times 100$. 


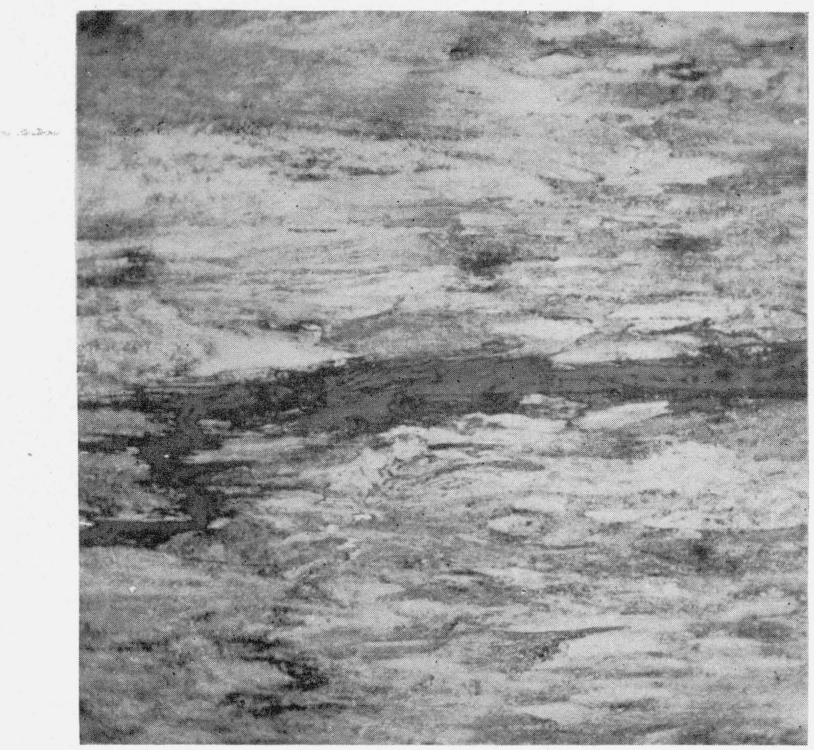

FIGURE 20.-Lower part of a stress-corrosion crack in a cold-drawn bridge wire (Portsmouth) to show its intercrystalline character in that region. Nital etching; $\times 500$.

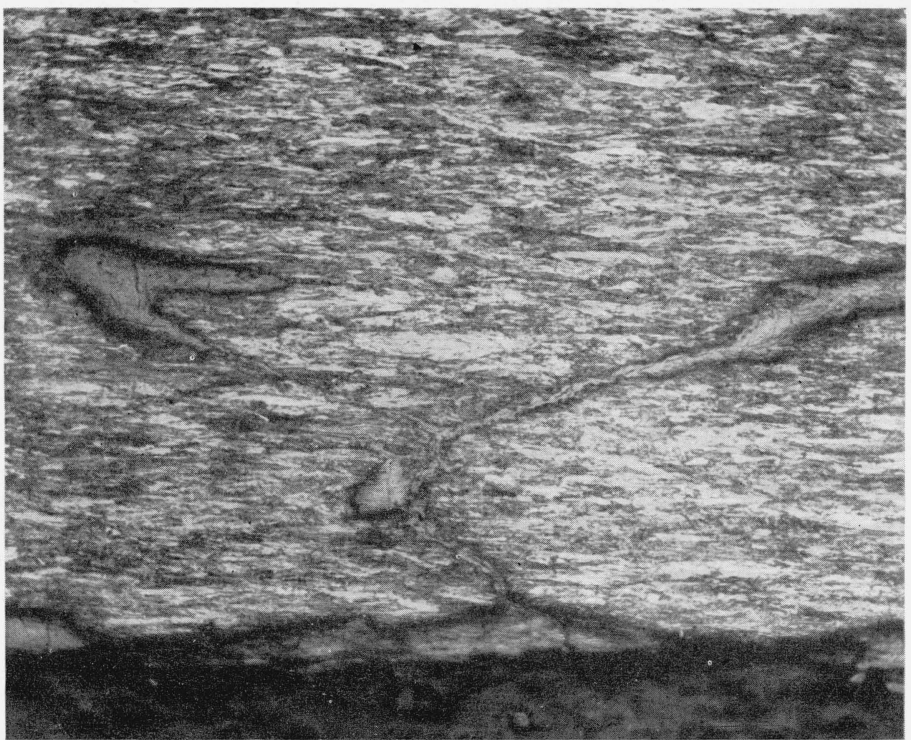

Figure 21.- Stress-corrosion crack on compression side of "bowed" specimen 29 of Portsmouth wire immersed in a nitrate solution.

It is probable that this crack occurred in service and was in the material as received. Nital etching; $\times 100$. 


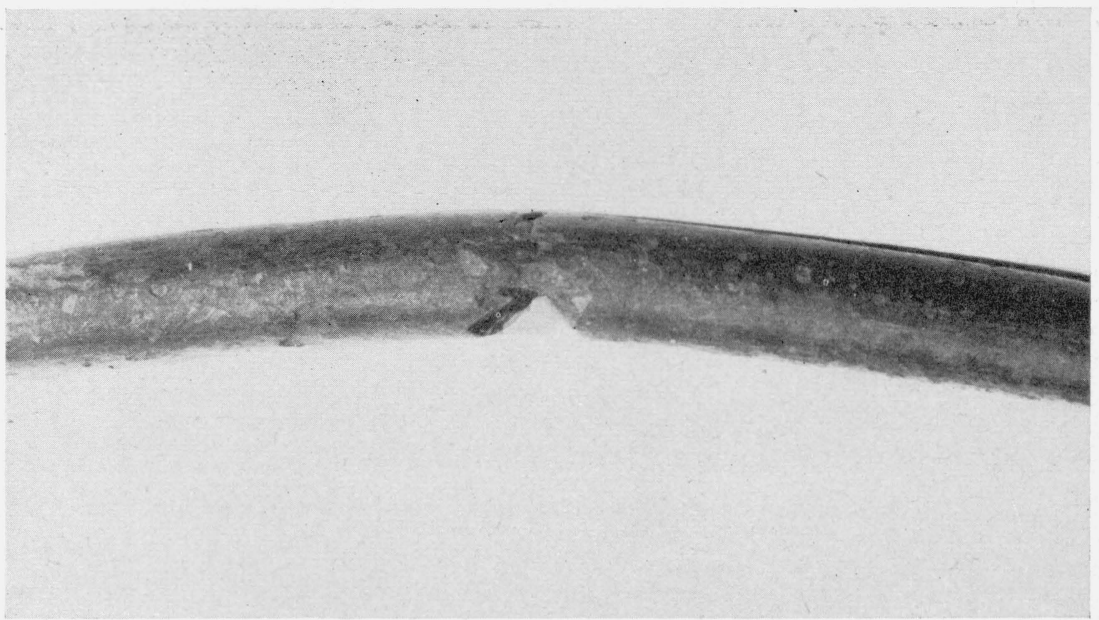

Figure 22.-Failure of "bowed" specimen 27, Portsmouth bridge wire, at a very deep localized pit after immersion, under static stress, in a $0.01 \mathrm{~N}$ solution of sodium nitrate for 13 months.

Aside from the local pit the specimen shows very little evidence of corrosive attack; $\times 3$.

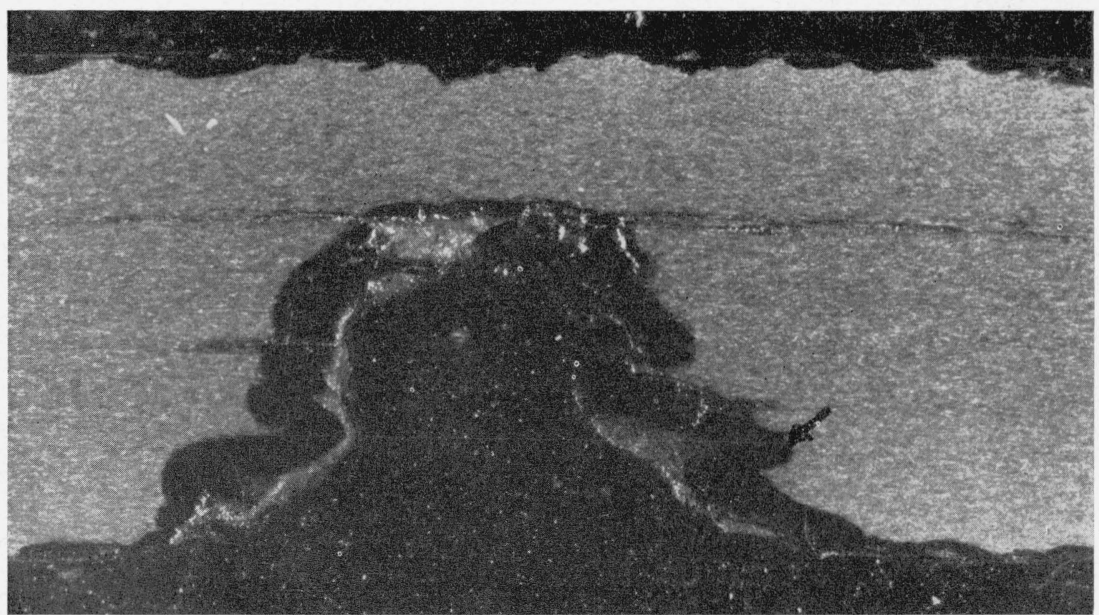

FIGURE 23.-Longitudinal section through deep pit of figure 22 on compression side of specimen 2\%, Portsmouth bridge wire.

Nital etching; $\times 12$. 


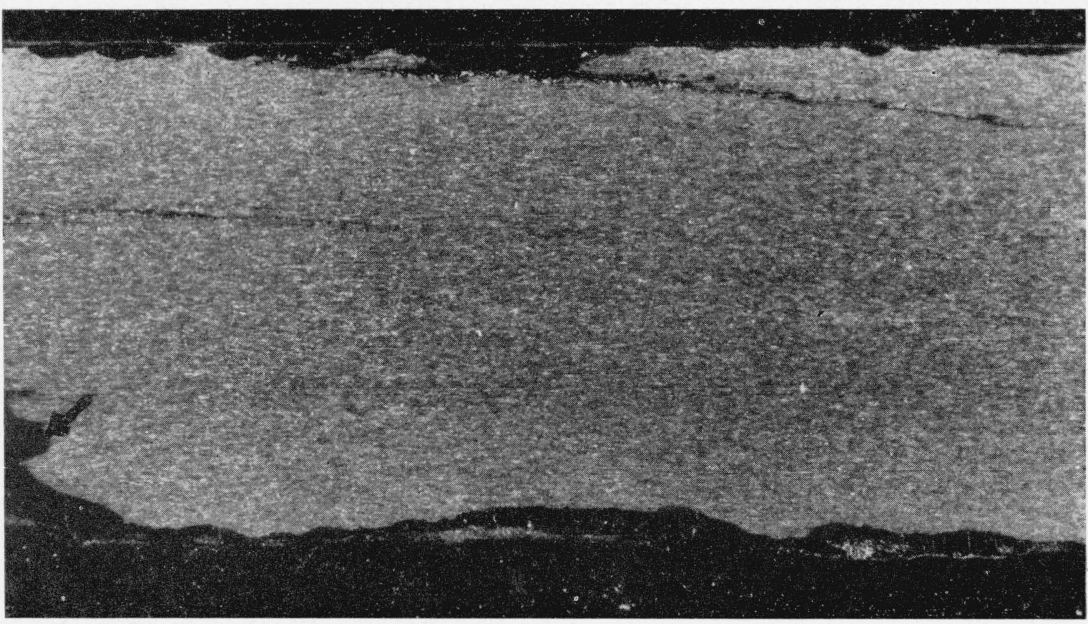

FiguRE 24.- Stress-corrosion crack on tension side of the same specimen shown in figures 22 and 23.

The location of the crack with respect to the pit is indicated by the arrow which points out an area common to both figures 23 and 24 .

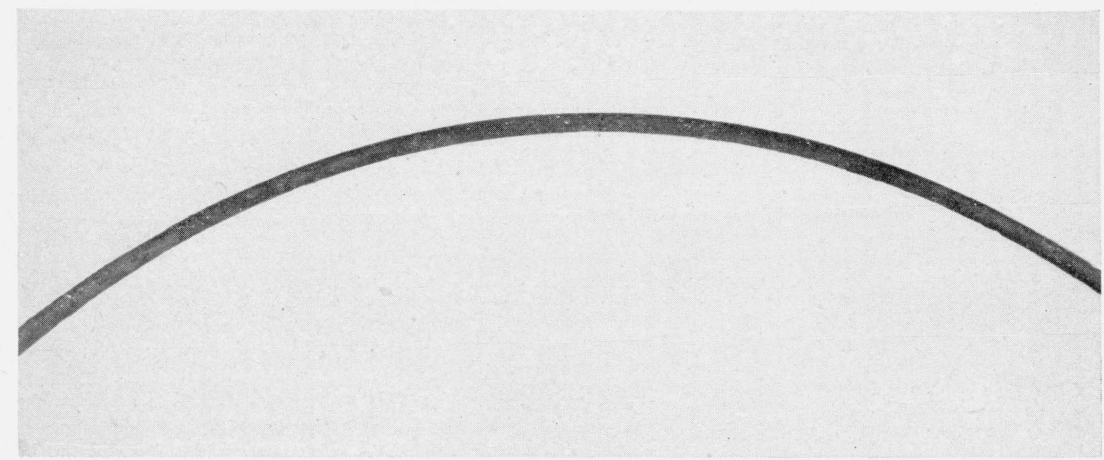

Figure 25.- "Bowed" specimen 30, Portsmouth bridge wire, which did not fail after immersion for 19 months in $0.01 \mathrm{~N}$ ammonium nitrate.

This is the only one of 14 samples of Portsmouth wire which did not fail in stress-corrosion tests in nitrate solutions; $\times 1 / 2$.

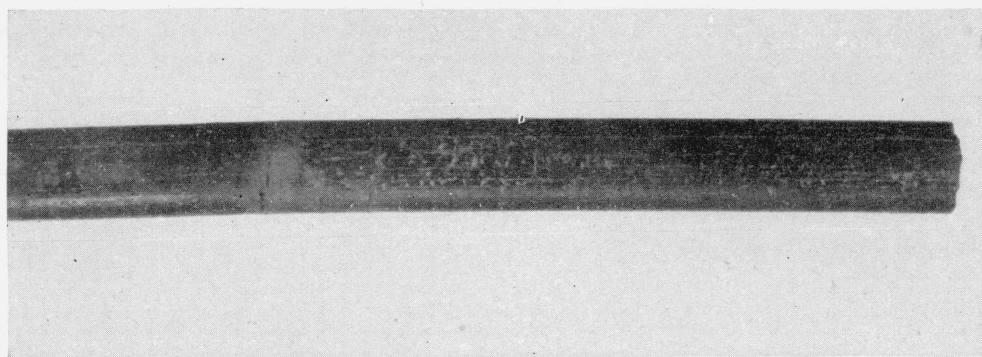

FiguRE 26.-Stress-corrosion fracture of "bowed" specimen H2, heat-treated Ml. Hope bridge wire immersed 5 months in a $0.01 \mathrm{~N}$ solution of ammonium nitrate; $\times 2$. 


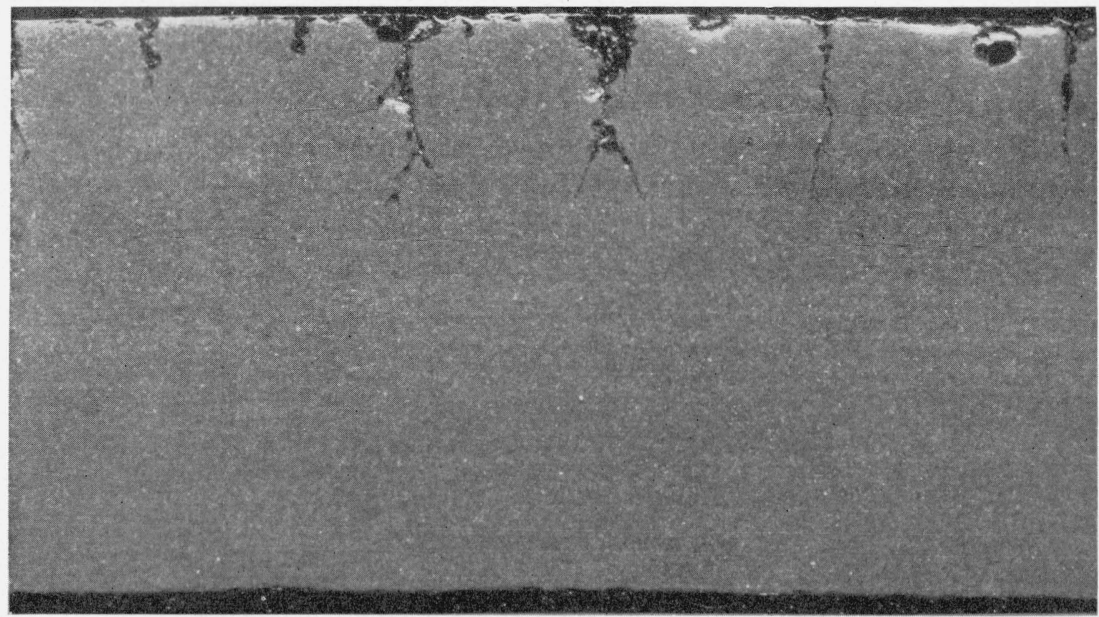

FIGURE 27.-Longitudinal section showing stress-corrosion cracks near the fracture of the specimen of heat-treated Mt. Hope bridge wire shown in figure 26.

Nital etching; $\times 12$.

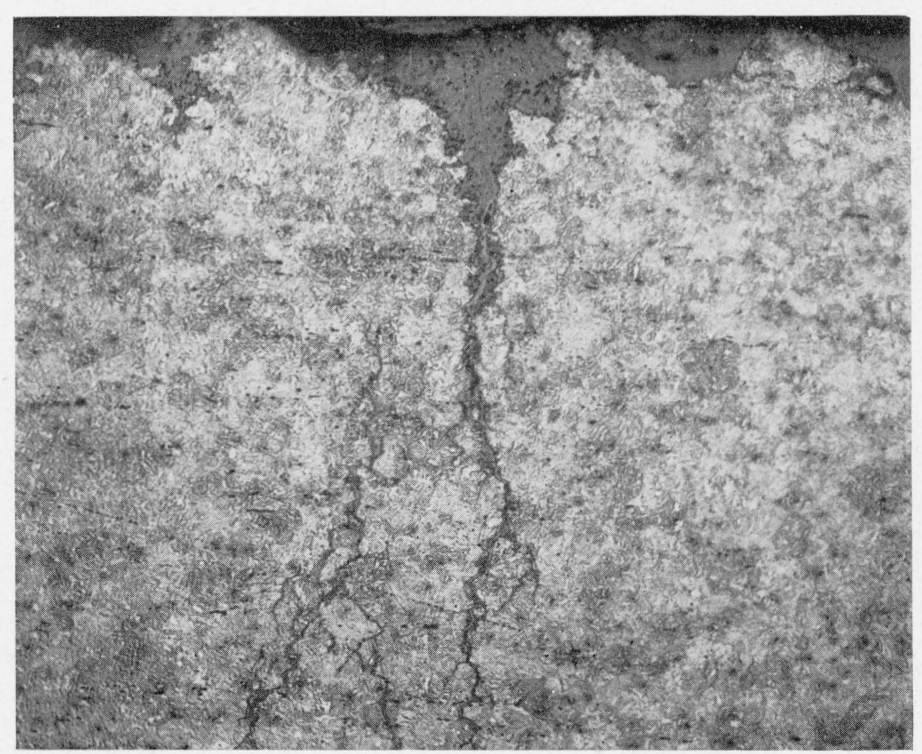

FIGURE 28.-One of the cracks of figure 27 at higher magnification.

The crack is intercrystalline over most of its course. Nital etching; $\times 100$. 


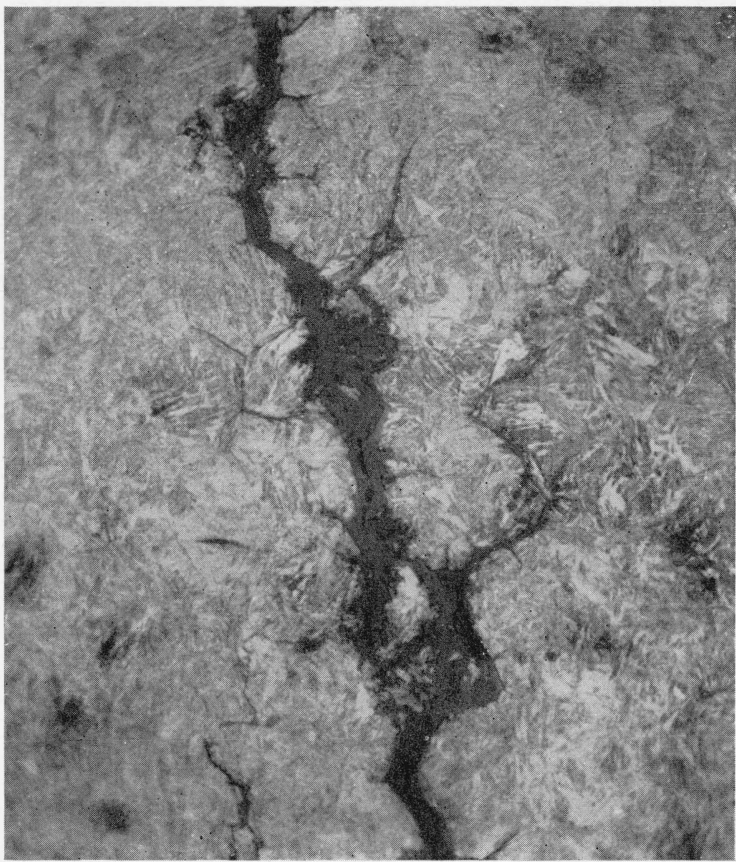

FIGURE 29.-Part of figure 28 at higher magnification showing the intercrystalline character of the crack and the quenched and tempered structure of the material.

\author{
Nital etching; $\times 100$.
}

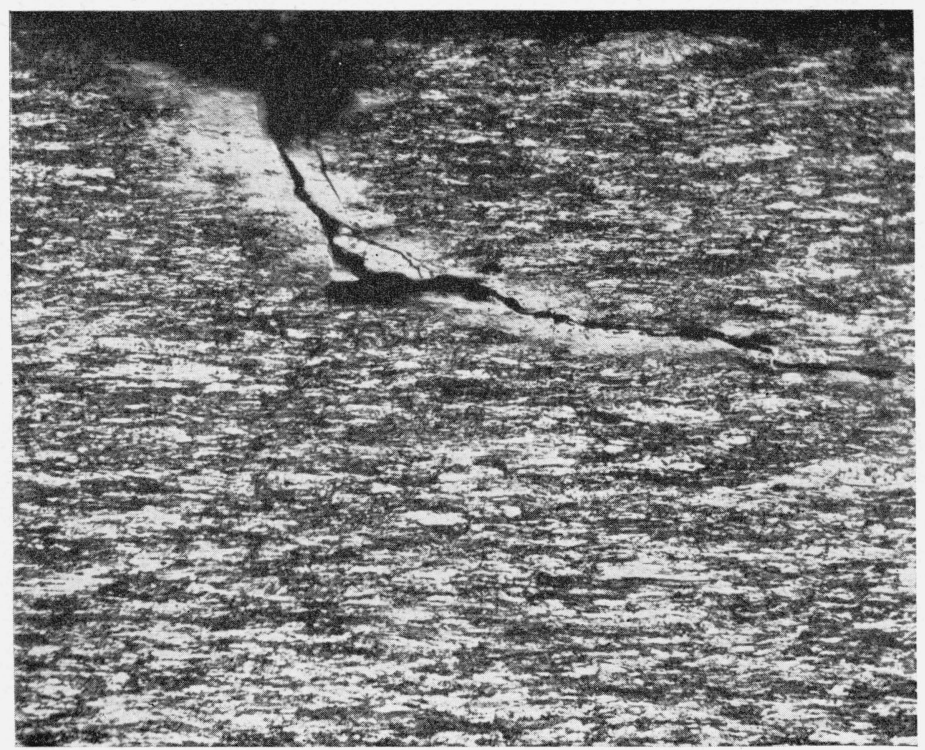

Figure 30.-Microstructure of the cold-drawn Portsmouth wire (specimen No. 25) in a longitudinal section showing a stress-corrosion crack.

Nital etching; $\times 100$. 


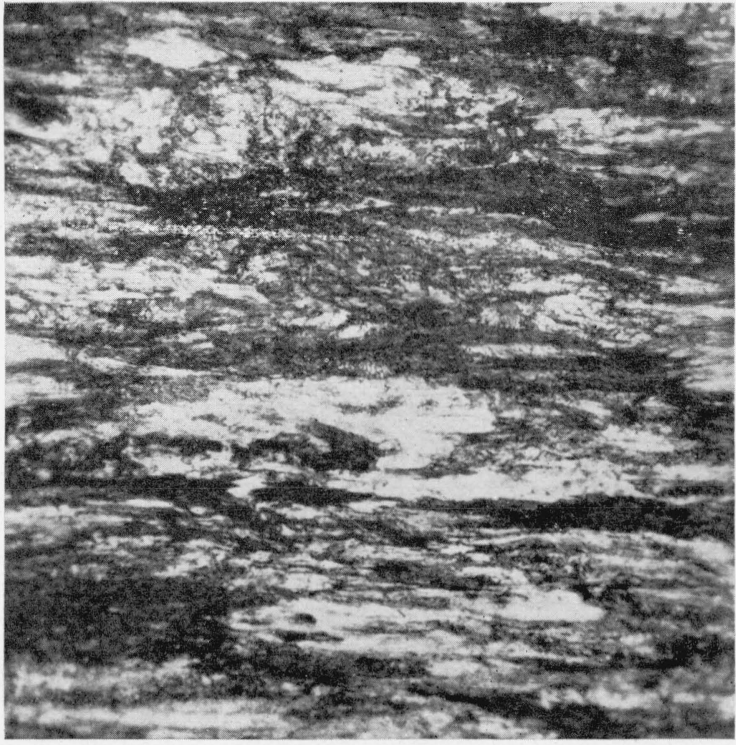

Figure 31.-Microstructure of cold-drawn Portsmouth wire at higher magnification.

Nital etching; $\times 500$.

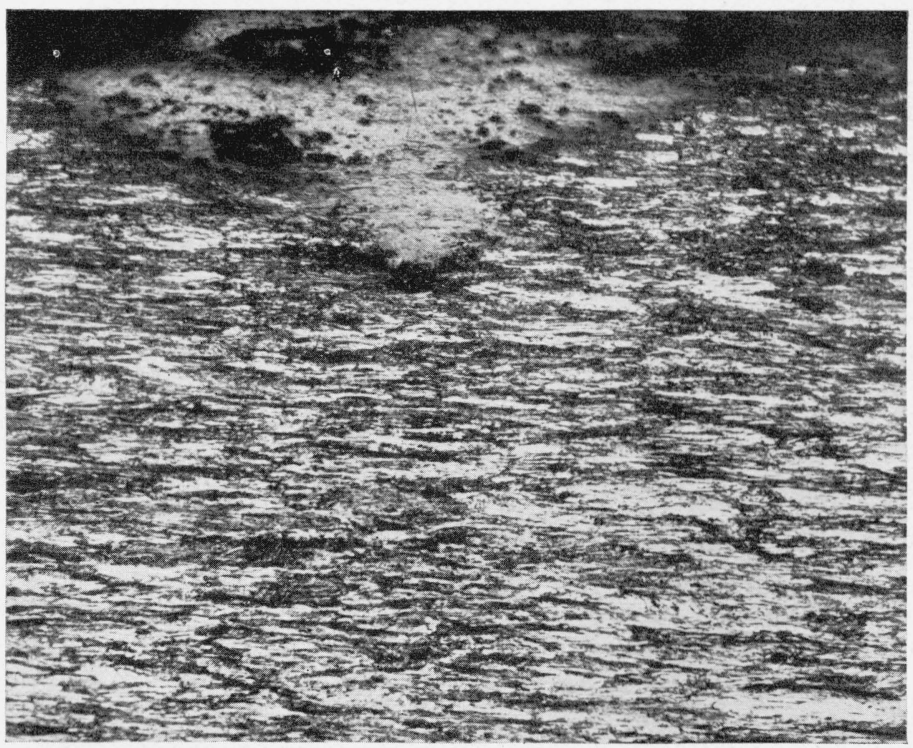

FIGURE 32.-Microstructure of cold-drawn Mt. Hope replacement wire (specimen H6) in a longitudinal section showing a deep corrosion pit produced by immersion for 40 months in $0.01 \mathrm{~N}$ ammonium nitrate. 


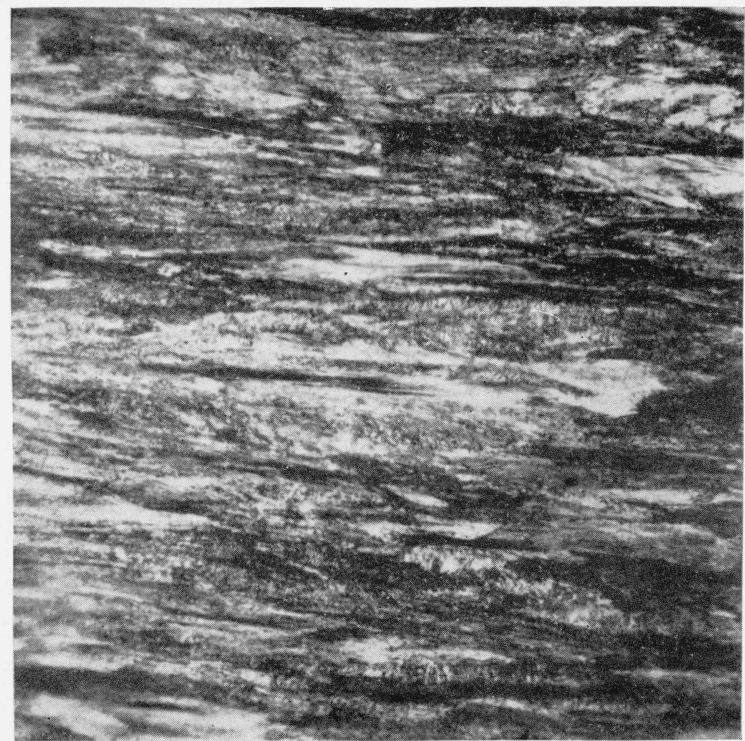

Figure 33.-Microstructure of cold-drown Mt. Hope replacement wire at higher magnification.

Nital etching; $\times 500$. 